\title{
Years Spent in Airlines Increase the Deep Acting Experience of Turkish Cabin Crew
}

\author{
SAVASS MUTLU \\ Department of Aviation Management, Civil Aviation School, Atılım University \\ Z. BENAN BÖKE
}

Civil Aviation Cabin Services Programme, Ankara Aeronautical Vocational School of Higher Education, University of Turkish Aeronautical Association

\begin{abstract}
The aim of this study is to find out the possible effects of demographic characteristics of cabin crew on their emotional labour experiences. The emotional labour concept was identified by Hochschild's subsequent research on Delta Airline's cabin attendants and was published in her book The Managed Heart: Commercialization of Human Feeling for the first time in the year 1983. In this study, 36 years after Hochschild's work, the effects of demographic characteristics on the emotional labour experiences of 265 flight attendants who work for airline companies in Turkey are investigated. In the literature
\end{abstract}


there are only a few studies on the effects of demographic factors on emotional labour experiences of cabin crew. So, this study provides an important insight into the subject. The emotional labour scale consists of three dimensions: deep acting, surface acting and genuine emotions. For the emotional labour, a total of 13 questions were answered by the participants in a 5-point Likert scale through the Internet. Also, six questions related to demographic characteristics were answered. An Exploratory Factor Analysis (EFA) was performed to verify the item distribution on each factor (i.e. deep acting, surface acting and genuine emotions). And, to analyse the differences between the emotional labour experiences of the groups according to their age, gender, position, marital status, total working experience and education, independent samples t-tests and one-way ANOVA tests were applied. Independent samples t-tests were used to compare the differences of two groups such as married-single, male-female, flight attendant-flight attendant supervisor. One-way ANOVA tests were used to compare the differences of three or more groups according to age, total working experience and education. Tukey HSD tests were performed after one-way ANOVA tests to distinguish the statistically different groups. The results show that there are no statistically significant differences between the expressions of emotional labour, deep acting, surface acting and genuine emotions of the groups according to gender, marital status, education and age. Yet, there are statistically significant differences between the emotional labour and surface acting experiences of flight attendants and flight attendant supervisors. Also, a statistically significant difference is found between the deep acting experiences of the cabin crew with 4-7 years of experience and those with 8-22 years of experience.

Keywords: emotional labour, cabin crew, deep acting, surface acting, genuine emotions JEL Classification Code: M12

\section{Introduction}

According to the International Air Transport Association (IATA) 4.1 billion passengers were carried by airlines all over the world in 2017. This data shows a 7\% increase in the number of passengers compared to the previous year (IATA, 2017). Turkey has a more significant increase in air passenger traffic than the world average (i.e. $11 \%$ in the year 2017). So, the airline sector is a fast growing one in Turkey and issues related to the development of human potential in this sector must be emphasised.

Today, the airline industry is very competitive and profit margins are very low. Because of the competition and cost reduction issues, it is getting more and more important to provide some non-price services to customers that can establish loyalty to the airlines. Since people are very important in services marketing, warm and friendly behaviour of cabin crew can be a competitive advantage for airlines. 
Employees spend different amounts of physical and mental effort in their work. But people working in the service sector; such as cabin crew, nurses, teachers etc., also spend emotional effort which is called emotional labour.

The first study on emotional labour was conducted by Hochschild, who introduced this concept to the literature in 1983. She defined emotional labour as "the management of feeling to create a publicly observable facial and bodily display" (Hochschild, 2003, p. 7).

Hochschild's research concentrated on the airline industry in the 1980s, particularly on US-based Delta Airline's flight attendants, mainly focusing on the training techniques for flight attendants to manage their emotions while dealing with passengers (Hochschild, 2003).

According to Hochschild's approach, there are two forms of emotional labour, 'surface acting' and 'deep acting'. The former can be described as a situation where behaviour is aligned with the goals of an organisation and regardless of an individual's own feeling at the time. On the other hand, deep acting is a conscious effort to harmonise one's own feelings with the expected behaviour (Hochschild, 2003, pp. 37-39).

Another study after Hochschild, (Ashforth \& Humprey, 1993, p. 94) stated that emotional labour may not necessarily be a conscious effort, and that it can come out as the result of actual feelings of an individual within this process. In this way, the third dimension was added to Hochshild's approach, namely 'genuine emotions'.

Deep acting enhances job performance and reduces burnout, while surface acting improves work performance at the cost of added burnout. This finding suggests that if airlines promote deep acting, they can improve their flight attendants' performance and reduce their burnout at the same time (Lee, An \& Noh, 2015, p. 409).

So, it is important to investigate the relationship between the demographic factors and the emotional labour which includes deep acting, surface acting and genuine emotions for cabin crew. In this study, 36 years after Hochschild's work, the effects of demographic characteristics on the emotional labour experiences of 265 flight attendants working for airline companies in Turkey are investigated.

As a general rule, those who work in the service sector should interact regularly with customers with different demographic characteristics. In these circumstances, they have to demonstrate organisationally required emotions regardless of their genuine emotions (Baruah \& Patrick, 2014, p. 41).

In the same way, there are two main tasks undertaken by cabin attendants that comply with the business model of any given airline, be it a full service network carrier, low-cost carrier, charter or a regional one, which are safety and service (Bergman \& Gillberg, 2015, p. 24). 
Flight attendants stay in direct contact with airline passengers for extended flight times, and the behaviour and emotional expressions can affect the perception of the passengers about the airline as a result (Hur, Moon \& Jun, 2013, p. 105).

Service is defined by Kotler and Armstrong (2006, p. 233) as "Any activity or benefit that one party can offer to another that is essentially intangible and does not result in the ownership of anything (e.g. Banking, hotel, airline, etc.)".

In addition to the traditional four Ps (product, price, promotion and place), in the service sector also another 3Ps are added, namely people, processes and physical evidence (Zeithaml\&Bitner, 2003). In this way, the attitudes and behaviours of flight attendants significantly influence customers' perceptions of airline services.

As airlines become more global through alliances, code sharing and network agreements, the human interaction between passengers and cabin crew as well as the emotional labour of the latter also gets more and more important (Whitelegg, 2002, p. 83).

In oligopolistic industries like airlines, companies tend not to reduce their prices to start price wars. Instead, they prefer non-price competition efforts such as increased advertisement and cabin services (Wensveen, 2007, p. 185).

In this challenging work environment, airline managers expect "consistent, caring and courteous" service performances from their cabin crew (Sheenan, 2012, p. 101).

If exceeding reasonable expectations, such services can also include advocate relationships between the airline company and the customer. This relationship is not only in terms of buying tickets from that same company, but also recommend to others to do so (Shaw, 2007, p. 243).

Based on the opinions mentioned above, the aim of the paper is to find out the possible effects of demographic characteristics of cabin crew on their emotional labour experiences. In the literature review there are only a few studies on this subject.

The emotional labour scale consists of three dimensions: deep acting, surface acting and genuine emotions. Using an Exploratory Factor Analysis (EFA), t-tests and one-way ANOVA, results show that there are no statistically significant differences between the expressions of emotional labour, deep acting, surface acting and genuine emotions of the groups according to gender, marital status, education and age.

Yet, there are statistically significant differences between the emotional labour and surface acting experiences of flight attendants and flight attendant supervisors, and between the deep acting experiences of the cabin crew with 4-7 years of experience and those with 8-22 years of experience. 


\section{Previous studies on the effects of demographic factors on cabin crew emotional labour experiences}

In the literature there are only a few studies on the effects of demographic factors on cabin crew emotional labour experiences. These are summarised below.

In their quantitative study, Baruah and Patrick (2014) investigated the influence of demographics (i.e. gender, age, marital status, and work tenure) on two forms of emotional labour (deep acting and surface acting) on 295 cabin crew and airline ground employees in India. The major findings of the study showed that emotional labour varies according to demographics. From the viewpoint of gender, male cabin crew experience less emotional labour than female ones, who express more deep acting than their male counterparts. Male cabin crew also express more surface acting.

In a study on 207 flight attendants in Istanbul, Turkey (Delen, 2017), it was found that seniority, marital status and age seriously affect the average emotional labour scores of the participants. Yet, on the other hand, no effect was detected as to gender, education level and work experience on the average emotional labour scores.

Ayuttacorn (2016, p. 54) stated that, with increasing flight years, female flight attendants have the experience to control their emotions in a professional way while performing their duties.

\section{Methodology}

In this research, we applied the positivist research philosophy, the deductive research approach, and a survey research strategy. A cross sectional study is performed. For data collection, a questionnaire was prepared with the sampling methods that include self-selection and snowball sampling (Saunders, Lewis \& Thornhill, 2003, p. 83). A total of 265 Turkish and non-Turkish flight attendants who work for airline companies in Turkey participated in the study through a questionnaire distributed via the Internet.

The emotional labour scale developed by Diefendorff, Croyle and Grosserand (2005, pp. 339-357) translated and adopted to Turkish by Basım and Beğenirbaş (2012, pp. 77-90) was used. The scale consisted of three dimensions: surface acting, deep acting and genuine emotions.

In the questionnaire there were thirteen items, six for surface acting, four for deep acting, and three for genuine emotions. Additionally, demographic questions related to age, gender, marital status, total working years, position, education were asked to the participants. 
This research was approved by the Human Research Ethics Board of Atılım University (At1lım University, 2018).

The participants answered the questions on a 5-point Likert scale ( $1=$ Strongly Disagree, 2 = Disagree, 3 = Neither agree nor disagree, $4=$ Agree, $5=$ Strongly Agree) . An Exploratory Factor Analysis (EFA) was performed to see the factor loadings of each item and to validate the predicted factor structure (Çokluk, Şekercioğlu \& Büyüköztürk, 2010, p. 177).

For this study the hypotheses are defined as follows:

H1. Among the cabin crews there is no difference in the experience of emotional labour according to demographics.

H2. Among the cabin crews there is no difference in the experience of deep acting according to demographics.

H3. Among the cabin crews there is no difference in the experience of surface acting according to demographics.

H4. Among the cabin crews there is no difference in the experience of genuine emotions according to demographics.

For all the hypotheses, the demographics are:

a. Age (Baruah \& Patrick, 2014; Delen, 2017);

b. Gender (Baruah \& Patrick, 2014; Ayuttacorn, 2016);

c. Marital status (Baruah \& Patrick, 2014; Delen, 2017);

d. Total working years (Baruah \& Patrick, 2014; Ayuttacorn, 2016);

e. Position (Delen, 2017);

f. Education (Delen, 2017).

To test the hypotheses two analyses were conducted, which are an independent samples t-test and a one-way ANOVA test. The independent samples t-test was applied for analysing the differences in emotional labour according to gender, marital status, and position. The independent samples t-test is a parametric test that is used to compare the statistical significance of the differences between the averages of two independently obtained sample groups (Büyüköztürk, Çokluk \& Köklü, 2011, p. 155).

The one-way ANOVA test was also applied for analysing the differences in emotional labour according to age, total working years and education. This test is applied when there is only one independent variable (Büyüköztürk, Çokluk \& Köklü, 2011, p. 191).

\section{Results}

According to the EFA results, Factor 1 (Deep Acting) comprised 6 items reported on a 5-point Likert scale explained $83 \%$ of the variance with factor loadings from .706 to .809; Factor 2 (Surface Acting) comprised 4 items reported on a 5-point 
Likert scale explained $9 \%$ of the variance with factor loadings from .753 to .897; and Factor 3 (Genuine Emotions) comprised 3 items reported on a 5-point Likert scale that explained $8 \%$ of the variance with factor loadings from .782 to .885 .

As shown in Table 2, the highest average is genuine emotions, followed by deep acting and emotional labour. The lowest average appears in surface acting.

One method to measure the reliability of the scale is Cronbach Alpha, and a minimum of 0.60 is accepted as a satisfactory value (Kavak, 2008, p. 157). As shown in Table 2, all Cronbach Alpha values (i.e. emotional labour, deep acting, surface acting and genuine emotions) are over 0.60 , thus, the scale is reliable.

Table 1. Sample group characteristics

\begin{tabular}{|c|c|c|}
\hline \multicolumn{3}{|c|}{$\mathrm{n}=265$} \\
\hline \multirow[t]{2}{*}{ Gender } & Female & $211(80 \%)$ \\
\hline & Male & $54(20 \%)$ \\
\hline \multirow[t]{5}{*}{ Age } & 30 and below & $77(29 \%)$ \\
\hline & $31-35$ & $59(22.2 \%)$ \\
\hline & $36-40$ & $32(12 \%)$ \\
\hline & $41-50$ & $70(26 \%)$ \\
\hline & Above 50 & $27(9.8 \%)$ \\
\hline \multirow[t]{5}{*}{ Total Working Years } & 3 years and below & $64(24 \%)$ \\
\hline & $4-7$ years & $68(25 \%)$ \\
\hline & $8-15$ years & $50(19 \%)$ \\
\hline & 16-22 years & $44(17 \%)$ \\
\hline & Above 23 years & $39(15 \%)$ \\
\hline \multirow[t]{4}{*}{ Education } & High School & $52(19.6 \%)$ \\
\hline & Vocational School & $67(25.3 \%)$ \\
\hline & Bachelor & $121(45.7 \%)$ \\
\hline & Master and above & $25(9.4 \%)$ \\
\hline \multirow[t]{2}{*}{ Marital Status } & Single & $164(61.9 \%)$ \\
\hline & Married & $101(38.1 \%)$ \\
\hline \multirow[t]{2}{*}{ Position } & Flight Attendant & $128(48.3 \%)$ \\
\hline & Flight Attendant Supervisor & $137(51.7 \%)$ \\
\hline
\end{tabular}

Source: own elaboration.

To perform the independent samples t-test, Levene's test must be insignificant (i.e. the probability must be 0.05 or more) to assume the variances as equal (Bryman \& Cramer,2005, p. 177). In this sample, all the Levene's test results assumed 
equal variances and according to independent samples t-test results, $\mathrm{H} 1 \mathrm{~b}, \mathrm{H} 1 \mathrm{c}, \mathrm{H} 2 \mathrm{~b}$, $\mathrm{H} 2 \mathrm{c}, \mathrm{H} 2 \mathrm{e}, \mathrm{H} 3 \mathrm{~b}, \mathrm{H} 3 \mathrm{c}, \mathrm{H} 4 \mathrm{~b}, \mathrm{H} 4 \mathrm{c}, \mathrm{H} 4 \mathrm{e}$ hypotheses are supported. This means that there is no statistically significant difference in experiences of emotional labour, deep acting, surface acting and genuine emotions according to gender and marital status.

\section{Table 2. Descriptive statistics}

\begin{tabular}{|l|c|c|c|c|}
\cline { 2 - 5 } \multicolumn{1}{c|}{} & $\mathrm{n}$ & Ave. & Std. Dev. & Cronbach Alpha $(\alpha)$ \\
\hline Emotional Labour (EL) & 265 & 3.23 & 0.563 & 0.753 \\
\hline Deep Acting (DA) & 265 & 3.30 & 0.961 & 0.887 \\
\hline Surface Acting (SA) & 265 & 2.99 & 0.944 & 0.882 \\
\hline Genuine Emotions (GE) & 265 & 3.60 & 0.841 & 0.819 \\
\hline
\end{tabular}

Source: own elaboration.

H1e is not supported, which means that there is a difference in the experience of emotional labour according to the position of the cabin crew. In other words, flight attendants experience more emotional labour than their supervisors $(M=3.36$, $\mathrm{SD}=0.55$ and $\mathrm{M}=3.11, \mathrm{SD}=0.55)$ conditions $\mathrm{t}(263)=3.57, \mathrm{p}=0.000$.

Also, H3e is not supported, implying that there is a difference in the experience of emotional labour based on the position. More specifically, flight attendants experience more surface acting than their supervisors $(\mathrm{M}=3.24, \mathrm{SD}=0.90$ and $\mathrm{M}=2.76, \mathrm{SD}=0.93)$ conditions $\mathrm{t}(263)=4.24, \mathrm{p}=0.000$.

The homogeneity of variances was measured by Levene's test, showing that the variance in none of the groups differed significantly, as the significance level is greater than 0.05 (Bryman \& Cramer, 2005, p. 182). The one-way ANOVA Test results show that H1a, H1d, H1f, H2a, H2f, H3a, H3d, H3f, H4a, H4d, and H4f are all supported. This means that there is no statistically significant difference in the experiences of emotional labour, deep acting, surface acting and genuine emotions according to age and education.

Since the value of the $\mathrm{F}$ test significance is lower than 0.05 in deep acting, a post hoc analysis is necessary to find out which group is different (Bayram, 2009, p. 148). Tukey HSD test showed that deep acting changes according to total working years, thus, not supporting H2d. There is a significant effect of the total working years on deep acting at the $\mathrm{p}<.05$ level for the three conditions $[\mathrm{F}(4,260)=3.91$, $\mathrm{p}=0.004]$. Tukey HSD test indicated that the mean score for $4-7$ total working years condition $(\mathrm{M}=2.96, \mathrm{SD}=1.00)$ is significantly different than $8-15$ total working years $(M=3.49, S D=1.04)$ and $16-22$ total working years $(M=3.59, S D=0.85)$. This means that the cabin crew who have $8-15$ and 16-22 of total working years experience more deep acting than those with 4-7 total working years. 


\section{Conclusion}

In this study, the effects of demographic characteristics on emotional labour experiences of 265 cabin crew working for airline companies in Turkey were investigated. Independent sample t-tests and one-way ANOVA tests were applied to determine the statistically meaningful differences between the groups according to age, gender, education, total working years, position and marital status.

The first conclusion from this study is that there are no statistically significant differences between the expressions of emotional labour, deep acting, surface acting and genuine emotions of groups according to gender, marital status, education and age. This finding does not support the findings of Baruah and Patrick (2014) which state that male cabin crew experience less emotional labour than female ones, while the female cabin crew express more deep acting than their male counterparts and male cabin crew express more surface acting than their female counterparts.

The second conclusion is that flight attendants experience more emotional labour than flight attendant supervisors. The reason for this can be the necessity of flight attendant supervisors to deal with more administrative duties, management of the cabin and cabin crew, and relations and coordination with the cockpit. As a result, they are less likely to come in contact with passengers.

The third conclusion shows that flight attendants express more surface acting than flight attendant supervisors. As explained earlier, flight attendants are likely to interact with passengers more than their supervisors, and given the intense working conditions, one may conclude that at those times flight attendants have to express emotions that they do not necessarily and genuinely feel.

As the fourth conclusion, cabin crew with 8-22 years of working experience more deep acting than those with 4-7 years' experience. This data supports the findings of Delen (2017), who argues that the seniority affects the average emotional labour scores of the participants. There can be two reasons to explain this situation. Firstly, as the years go by, these individuals learn how to manage and express their internal emotions instead of expressing feelings unwillingly. In this way they can also harmonise their feelings with the goals of the company that they are working for. Secondly, the cabin crew whose expectations are in line with organisational expectations may stay longer in their company.

There is a high competition between airlines all over the world. Since airlines are operating with low profit margins, non-price efforts such as kind and helpful in-flight service of cabin crew are becoming more and more important for the competitive advantage. As the frontline employees of the airlines, cabin crews' deep acting experiences with the passengers can provide this advantage for their airlines. 
Also, deep acting can reduce the burnout of cabin crew and help them to avoid the stress in such hard working conditions.

The airlines in Turkey generally hire inexperienced cabin crew between ages 21-30 and for experienced cabin crew between ages 35-40. They tend to employ younger cabin crew on board and usually appoint them as trainer and ground support staff within the airlines or expect them to retire after the age of 45-50.

However, as seen from the results of the study, cabin crew experience more deep acting in their older age. Therefore, it can be suggested that senior cabin crew above the age of 45 should be given a chance to continue flying and practise their profession in airline companies in Turkey.

In the literature, there are only a few studies on the effects of demographic factors on emotional labour of cabin crew. Therefore, it is necessary to perform new studies with more cabin crew participants from various airlines in the world.

\section{References:}

Ashford, B.E., \& Humprey, R.H. (1993). Emotional Labor in Service Roles: The Influence of Identity. Academy of Management Review, 18(1), 88-115.

Atılım University Ethics Board Permission (2018). No. 59394181-604.01.01-5591 (12.09.2018).

Ayuttacorn, A. (2016). Winyann and Affective Performance Among Female Thai Flight Attendants. The Asia Pacific Journal of Anthropology, 17(1), 50-65.

Baruah, R., \& Patrick, H.A. (2014, December). Influence of Emotional Labour on General Health of Cabin Crew and Airline Ground Employees. Journal of Education \&social Policy, 1(2).

Basım, H.N., \& Beğenirbaş M. (2012). Çalışma Yaşamında Duygusal Emek: Bir Ölçek Uyarlama Çalışması. Celal Bayar Üniversitesi İ.I. B. F. Yönetim ve Ekonomi, 19(1), 73-90. Bayram, N. (2009). Sosyal Bilimlerde SPSS ile Veri Analizi. Bursa:Ezgi Kitabevi, 235. Bergman, A., \& Gillberg G. (2015). The Cabin Crew Blues: Middle-aged Cabin Attendants and Their Working Conditions. Nordic journal of working life studies, 5(4), 23-39.

Bryman, A., \& Cramer, D. (2005). Quantitative Data Analysis with SPSS 12 and 13. New York: Routledge.

Büyüköztürk, Ş., Çokluk, Ö., \& Köklü, N. (2011). Sosyal Bilimler için İstatistik. Ankara: Pegem Akademi.

Çokluk, Ö, Şekercioğlu, G., \& Büyüköztürk, Ş. (2010). Sosyal Bilimler için Çok Değişkenli İstatistik: SPSS ve LISREL Uygulamaları. Ankara: Pegem Akademi.

Delen, M.G. (2017). Individual Antecedents of Emotional Labour in Airline Industry. Beykent Üniversitesi Sosyal Bilimler Dregisi (BUJSS), 10(1), 1-15. 
Diefendorff, J.M., Croyle, M.H., \& Grosserand, R.H. (2005). The Dimensionality and Antecedents of Emotinal Labor Strategies. Journal of Vocational Behavior, 66, 339-357.

Hochschild, A.R. (2003). The Managed Heart: Commercialization of Human Feeling. California: University of California Press.

Hur, W.M., Moon, T.W., \& Jun, J.K. (2013). The Role of Perceived Organizational Support on Emotional Labor in the Airline Industry. International Journal of Contemporary Hospitality Management, 25(1), 105-123.

IATA (2017). More Than 7\% increase in Air Travel Compared to Last Year. Retrieved from: http://www.iata.org/pressroom/pr/Pages/2017-10-09-01.aspx (13.10.2017).

Kavak, B. (2008). Pazarlama Araştırmaları Tasarım ve Analiz. Ankara: Hacettepe University, 283.

Kotler, P., Armstrong, G. (2006). Principles of Marketing. New Jersey: Pearson Prentice Hall.

Lee, C., An, M., \& Noh, Y. (2015, September). The Effects of Emotional Display Rules on Flight Attendants' Emotional Labor Strategy, Job Burnout and Performance. Service Business, Springer; Pan-Pacific Business Association, 9(3), 409-425.

Saunders, M., Lewis, P., \& Thornhill, A. (2003). Research Methods for Business Students. England: Pearson Education.

Shaw, S. (2007). Airline Marketing and Management. Ashgate.

Sheenan, C. (2012). Hard Labour at 35,000 Feet: A Reconsideration of Emotional Demands in Airline Service Work. Hospitality \&society, 2(1), 99-116.

Whitelegg, D. (2002). Cabin Pressure: The Dialectics of Emotional Labour in the Airline Industry. The Journal of Transport History, 23(1), 73-86.

Wensween, J.G. (2007). Air Transportation: A Management Perspective. Ashgate.

Williams, C. (2003, November). Sky Service: The Demands of Emotional Labour in the Airline Industry. Gender, Work and Organization. 10(5), 513-550.

Zeithaml, V.A., \& Bitner, M.J. (2003). Services Marketing: Integrating Customer Focus Across the Firm. New York, U. S: McGraw-Hill.

\section{Savaş Mutlu}

Assistant Professor, PhD. He worked for more than 20 years in the public sector. Now, he is the chairperson of the Aviation Management Department at Atılım University, Civil Aviation School. His research interests are aviation management, organisational behaviour and human resources management.

e-mail address: savas.mutlu@atilim.edu.tr 


\section{Z. Benan Böke}

Lecturer. She worked as a Flight Attendant, Cabin Crew Supervisor, Check Airman, Cabin Crew Instructor and Cabin Crew Manager in international and domestic airlines between 1991-2011. Since 2012, she has been a lecturer of Cabin Services and Aviation at Atılım and UTAA Universities. She is also a PhD student. Her research interests particularly lie in the area of Aviation and Business Administration.

e-mail address: zbboke@thk.edu.tr 